\title{
Analysing the livelihood options of rural women in Theni district
}

\author{
M.V. KARUNA JEBA MARY, C. KARTHIKEYAN AND T.N. SUJEETHA
}

Received : 25.09.2014; Revised : 08.02.2015; Accepted : 23.02.2015

\begin{abstract}
A study was conducted in the Theni district of Tamil Nadu with the general objective to find out the changes in livelihood pattern of the rural women. Three blocks that had maximum number of tanks viz., Periyakulam, Andipatti and Bodinayakkanur were selected. Two villages were purposively selected from each of the block. These villages had tanks that were functioning to the extent of supporting the livelihood of SHG women considerably. Accordingly, six representative SHGs were selected drawing members of one SHG from each of the selected villages. All the members of the selected six SHGs constituted the sample for the study. Thus, the total sample size of the study is 102 SHG women. The respondents were interviewed personally by a well-structured interview schedule. The results of the study revealed that 39.22 per cent of rural women were pursuing occupation in service sector, 35.30 per cent in agriculture.
\end{abstract}

KEY WORDS : Livelihood options, Rural women

How to cite this paper : Mary, M.V. Karuna Jeba, Karthikeyan, C. and Sujeetha, T.N. (2015). Analysing the livelihood options of rural women in Theni district. Internat. J. Com. \& Bus. Manage, 8(1) : 23-27.

\section{MEMBERS OF THE RESEARCH FORUM}

Correspondence to:

M.V. KARUNA JEBA MARY, Directorate of Centre for Agricultural and Rural Development Studies, Tamil Nadu Agricultural University, COIMBATORE (T.N.) INDIA

Email: jebamaryextn@gmail.com

Authors' affiliations:

C. KARTHIKEYAN, Agricultural and E-Extension Centre, Tamil Nadu Agricultural University, COIMBATORE (T.N.) INDIA

T.N. SUJEETHA, Department of Agricultural Extension and Rural Sociology, Tamil Nadu Agricultural University, COIMBATORE (T.N.) INDIA 